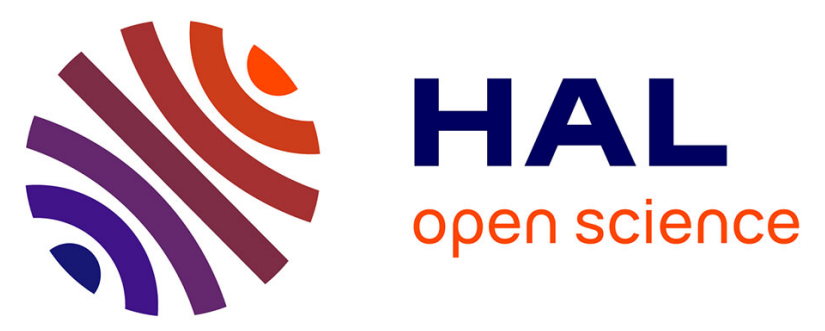

\title{
Thermo-mechanical performance of Carbon Fiber Reinforced Polymer (CFRP), with and without fire protection material, under combined elevated temperature and mechanical loading conditions
}

Phi Long Nguyen, Xuan Hong Vu, Emmanuel Ferrier

\section{- To cite this version:}

Phi Long Nguyen, Xuan Hong Vu, Emmanuel Ferrier. Thermo-mechanical performance of Carbon Fiber Reinforced Polymer (CFRP), with and without fire protection material, under combined elevated temperature and mechanical loading conditions. Composites Part B: Engineering, 2019, 169, pp.164 - 173. 10.1016/j.compositesb.2019.03.075 . hal-03480691

\section{HAL Id: hal-03480691 \\ https://hal.science/hal-03480691}

Submitted on 20 Dec 2021

HAL is a multi-disciplinary open access archive for the deposit and dissemination of scientific research documents, whether they are published or not. The documents may come from teaching and research institutions in France or abroad, or from public or private research centers.
L'archive ouverte pluridisciplinaire HAL, est destinée au dépôt et à la diffusion de documents scientifiques de niveau recherche, publiés ou non, émanant des établissements d'enseignement et de recherche français ou étrangers, des laboratoires publics ou privés.

\section{(c) (1) $\$$}

Distributed under a Creative Commons Attribution - NonCommerciall 4.0 International 
1 Thermo-mechanical performance of Carbon Fiber Reinforced Polymer

${ }^{a}$ Université de LYON, Université Claude Bernard LYON 1; Laboratoire des Matériaux Composites pour la Construction

${ }^{b}$ Ho Chi Minh City University of Transport, Faculty of Construction Engineering, Campus 1: Number 2, Vo Oanh Street (precedent name: D3 street), Ward 25, Binh Thanh Disctrict, Ho Chi Minh City, Vietnam.

9

\title{
(CFRP), with and without fire protection material, under combined
} elevated temperature and mechanical loading conditions

\author{
Phi Long NGUYEN ${ }^{\mathrm{a}, \mathrm{b}}$, Xuan Hong VU ${ }^{\mathrm{a}, *}$, Emmanuel FERRIER ${ }^{\mathrm{a}}$
}

LMC2, France

\section{ABSTRACT}

In civil engineering, when a CFRP-reinforced structure is subjected to fire, both the structure and CFRP are simultaneously affected by elevated temperature and mechanical loading. In the Eurocodes, the strengths of concrete and steel are described to be reduced with increased temperature; however, the codes do not describe the performance of hand-laid CFRP. This paper presents the thermomechanical performance of hand-laid CFRP with and without thermal insulation under different mechanical loading conditions. Experimental tests were conducted to identify the maximum transient heating temperature and duration to which CFRP can be exposed at different levels of mechanical load. The results show that when the applied load increases, the rupture temperature and maximum exposure duration decrease. At $20^{\circ} \mathrm{C}$, the rupture temperature of CFRP gradually decreases when the applied load increases from $10 \%$ to $50 \%$ of the material's ultimate strength; at room temperature, as the applied load reaches $75 \%$ of the ultimate strength, the rupture temperature significantly decreases.

\footnotetext{
${ }^{*}$ Corresponding author.

E-mail adresses : Xuan-Hong.Vu@univ-lyon1.fr (X.H. VU), phi-long.nguyen@etu.univ-lyon1.fr or long.nguyen@ut.edu.vn (P.L. NGUYEN), emmanuel.ferrier@univ-lyon1.fr_E. FERRIER)
} 
Likewise, the exposure duration gradually decreases when the applied load varies from $10 \%$ to $50 \%$ of CFRP's ultimate strength, and decreases considerably when the applied load is $75 \%$ of the ultimate strength. Additional tests were conducted on CFRP protected by an insulation material to characterize the effectiveness of the used insulation material used on the performance of hand-laid CFRP subjected to thermal and mechanical loading. Finite element models were used to investigate the thermal conduction, and these models were successfully validated by the experimental results. Thus, the models were confirmed to predict the fire protection capability of the used insulation material reliably and accurately.

Keywords: carbon fibre reinforced polymer (CFRP); elevated temperature; thermo-mechanical behaviour; fire protective system

\section{Introduction}

In recent decades, carbon fibre reinforced polymer (CFRP) has been increasingly used in civil engineering applications for both reinforcing and retrofitting structures. With its advantages of a high strength-to-weight ratio and favourable corrosion and fatigue resistance, CFRP is often employed to enhance the strength, stiffness and ductility of concrete structures such as columns, beams, and slabs. There are two major methods of applying CFRP in these contexts: by directly bonding a laminate CFRP plate, known as pultruded-CFRP (P-CFRP), on the surface of a concrete structure using adhesive, or by wrapping woven textile CFRP around the concrete structure and securing it with resin. In the latter method, the CFRP is referred to as in-situ CFRP, hand-laid CFRP, or manually-fabricated CFRP (M-CFRP). The following subsections present previous studies on the temperature-dependent behaviour of CFRP, the effects of fire or elevated temperatures on structures strengthened by Fiber 
Reinforced Polymer (FRP) without and with insulation material, and the objectives of this study.

\subsection{Temperature-dependent behaviour of CFRP}

Since CFRP's first application in civil engineering, there has been tremendous interest in its functional capability in fire conditions. Considerable research has focused on the mechanical performance and properties of P-CFRP at elevated temperatures. However, to the best of the authors' knowledge, the performance of hand-laid CFRP under elevated temperatures (above $200^{\circ} \mathrm{C}$ ) has not yet been studied. Over past decades, several researchers have focused on the evolution of the tensile performance of P-CFRP following two popular procedures: in the first procedure, specimens were heated to a predefined temperature and then mechanically tested until rupture following a direct tensile test program (thermo-mechanical procedure); in the second procedure, after being heated to a predefined temperature and then cooled to an ambient temperature, specimens were tested following a direct tensile test program at room temperature (residual procedure). Particularly, Y.C. Wang et al. performed a series of tensile tests on P-CFRP at temperatures ranging from $20^{\circ} \mathrm{C}$ to $600^{\circ} \mathrm{C}$ following the thermo-mechanical procedure [1]. Their results showed that the tensile strength of P-CFRP is reduced by approximately $50 \%$ as the temperature increases up to $240^{\circ} \mathrm{C}$, and at $600^{\circ} \mathrm{C}$, its tensile strength was reduced by almost $90 \%$. K. Wang et al. measured the tensile strength of a P-CFRP strip following the thermo-mechanical procedure at temperatures ranging from $22^{\circ} \mathrm{C}$ to $706^{\circ} \mathrm{C}$ [2]. Their results demonstrated that the P-CFRP strip's tensile strength was reduced by approximately $50 \%$ at $350^{\circ} \mathrm{C}$ and by more than $80 \%$ at $600^{\circ} \mathrm{C}$. Yu and Kodur studied the influence of temperature between $20^{\circ} \mathrm{C}$ to $600^{\circ} \mathrm{C}$ on the degradation of the tensile properties of P-CFRP strips and rods following the thermo-mechanical procedure [3]. Their results showed that the tensile strength was reduced by approximately $50 \%$ for strips and $40 \%$ for rods at $300^{\circ} \mathrm{C}$, and by approximately $90 \%$ for both strips and rods at $600^{\circ} \mathrm{C}$; furthermore, the tensile modulus decreased by approximately 
$30 \%$ for both strips and rods at $400^{\circ} \mathrm{C}$ and by $67 \%$ and $47 \%$ at $500^{\circ} \mathrm{C}$ for strips and rods, respectively. Cao et al. tested the thermo-mechanical tensile strength of CFRP sheets (M-CFRP) with two different methods of loading control (by load and displacement increments) between $16^{\circ} \mathrm{C}$ and $200^{\circ} \mathrm{C}$ [4]. Their results indicated that the tensile strength of $\mathrm{CFRP}$ sheets was significantly reduced with increasing temperature: from $16^{\circ} \mathrm{C}$ to $55^{\circ} \mathrm{C}$, the tensile strength was reduced by approximately $30 \%$, and remained in the vicinity of this value until $200^{\circ} \mathrm{C}$. The tensile and lap-splice shear strength properties of M-CFRP composites [5] at temperatures ranging from $23^{\circ} \mathrm{C}$ to $200^{\circ} \mathrm{C}$ have been performed. Recently, Nguyen et. al. experimentally and analytically studied the behaviour of hand lay-up CFRP under simultaneous thermal and mechanical loadings with the elevated temperature upto $600{ }^{\circ} \mathrm{C}[6]$. The results showed that the ultimate strength decreased by $50 \%$ at $350{ }^{\circ} \mathrm{C}$ while the Young's modulus only decreased by $30 \%$ at $600{ }^{\circ} \mathrm{C}$.

When subjected to a thermal load, most thermosetting resins and amorphous polymers show one major transition, which occurs within a narrow temperature range called the glass transition temperature $(\mathrm{Tg})$. The $\mathrm{Tg}$ of commercial products used in civil infrastructure applications varies between $50^{\circ} \mathrm{C}$ and $90^{\circ} \mathrm{C}$ [7]. When the temperature in the material reaches the $\mathrm{Tg}$ of the polymer matrix, the matrix becomes softer, and its mechanical properties (Young's modulus, tensile strength) are significantly reduced. Therefore, the contribution of the matrix to the composite's tensile strength gradually becomes negligible. This contribution reduces to zero after the total decomposition of the matrix, characterized by a decomposition temperature, $\operatorname{Td}\left(250^{\circ} \mathrm{C}-500^{\circ} \mathrm{C}\right)[7,8]$. The matrix decomposition process usually releases heat, smoke, soot and toxic and/or combustible volatiles [8]. This possibly accelerates the matrix decomposition, influences the mechanical properties of the fibre and also restrains the deformation measurement.

\subsection{Effects of fire or elevated temperatures on structures strengthened by FRP} without and with insulation material 
When a fire occurs, structures and FRP-reinforced materials are subjected to heat and mechanical loads at the same time. Several investigations have focused on the performance of CFRP-reinforced concrete structures under fire or near-fire conditions [10-14]. Bisby et al. investigated the residual performance of CFRP-reinforced concrete beams and columns subjected to fire [10]. The residual confining performance of an externally wrapped

101 specimen secured by normal-temperature epoxy and then exposed to fire has been studied

102 [11]. The fire performance of CFRP-reinforced concrete beams under various mechanical load levels has also been investigated [12]. Al-Abdwais et al. observed concrete structures reinforced by CFRP with a cement-based adhesive at elevated temperatures [13]. Firmo et al. experimentally studied the performance of a CFRP-reinforced concrete beam at an ambient temperature and numerically developed these results to describe the fire performance of 107 CFRP-reinforced concrete structures [14].

Additional research has been conducted on the shear and compression strengths of concrete structures or pretensioned CFRP-reinforced slabs under various temperature and mechanical conditions. Masoud et al. numerically studied the performance of a concrete slab

111 reinforced by FRP bars at elevated temperatures, disregarding the degradation of the bonding

112 between the FRP bars and concrete [15]. The application of their results was recommended 113 only where the CFRP bars were anchored to prevent bond failure in a fire. Hajiloo et al. 114 investigated the performance of concrete slabs reinforced by FRP bars under $55 \%$ of the 115 ultimate moment resistance in a fire condition [16]. Their results indicated anchoring 116 recommendations that can maintain the structure's performance for up to $3 \mathrm{~h}$. Tan et al. 117 investigated the residual shear-strengthening performance of a glass FRP-wrapped beams 118 after exposure to a temperature-time history [17], following ASTM E-119 [18]. Tan et al. 119 also reported on the performance of a fibre-reinforced cement composite, basalt FRP 120 laminates, and basalt FRP-strengthened beams subjected to elevated temperatures [18-20]. 121 Terrasi et al. and Maluk et al. reported on the fire behaviour of CFRP prestressed 
high-performance self-consolidating concrete (HPSCC) slabs through an experimental study

123 on thin slabs exposed to a standard fire [21, 22]. Among the main concerns with

124 FRP-reinforced structures at elevated temperatures is the effect of the adhesive-substrate

125 bond strength on the structural performance [23-30]. Several reinforcement methods and

126 adhesive types have been proposed to improve the adhesive-substrate bond performance

127 under elevated temperature or fire conditions. Non-structural solutions to improve the

128 performance of CFRP-reinforced structures under fire conditions include several insulation

129 systems that have been proposed to protect the structures so that the service duration can be

130 extended to meet fire safety requirements [8, 23-27, 31-39]. Various fire regulations

131 recommend protecting structural elements with certain insulation materials requirements [23,

132 24], or protecting only the anchorage zone $[8,25-27,34,36,37]$. Further recommendations

133 have been made with regard to different material types, such as vermiculite/gypsum mortar

134 insulation material [31, 32] or vermiculite/perlite mortar insulation [36]. Numerical models

135 have also been proposed to investigate the efficiency of insulation materials in terms of

136 enhancing the fire performance of FRP-reinforced structures [34, 40-42]. Bond loss between

137 CFRP composites and concrete substrate without insulation protection has also been

138 analysed and modelled by Dai et al. as well as Biscaia et al. [43-47].

$139 \quad$ 1.3. Objectives of this study

140 As noted in previous research, to the best of the authors' knowledge, very few studies have

141 focused on the thermo-mechanical behaviour of hand-laid CFRP and the performance of this

142 material under combined elevated temperatures (above $200^{\circ} \mathrm{C}$ ) and mechanical loading

143 conditions has not yet been experimentally studied. There are also no experimental or

144 numerical results regarding the insulation material's capability to protect hand-laid CFRP

145 under combined elevated temperatures and mechanical loading. In this research, the

146 performance of a hand-laid CFRP simultaneously exposed to elevated temperature and

147 mechanical loading was investigated to determine the temperature and duration of exposure 
at which failure occurred. An insulation material was also experimentally tested for its thermal performance and was then applied to thermally protect the CFRP material in the thermo-mechanical testing regime. The efficiency of the insulation material was then analysed and numerically extended to the fire-temperature condition.

\section{Experimental materials and methods}

This section presents experimental devices, specimens and experimental procedures that were used for this study.

\subsection{Experimental devices}

In this research, a thermo-mechanical testing system (Figure 1) was used to study the thermo-mechanical behaviour of a M-CFRP material. The system included two main parts: a thermo-mechanical machine (TM20kN-1200C) and a laser extensometer. During the test, the TM20kN-1200C controlled the force and temperature applied on the sample according to a determined procedure, and the laser extensometer measured the elongation of the M-CFRP specimen, from which the tensile axial strain of the sample was calculated [49].

$$
\text { The TM20kN-1200C included a mechanical component (Figure 1a) and a furnace }
$$
(Figure 1b). The mechanical component can apply direct tensile loading onto the test specimen with a loading capacity of up to $20 \mathrm{kN}$ at a programmable loading speed. The furnace was a cylindrical oven with external dimensions of $40 \mathrm{~cm}$ in height and $30 \mathrm{~cm}$ in diameter, and the dimensions of the oven's heating chamber were $28 \mathrm{~cm}$ in height and $10 \mathrm{~cm}$ in diameter. This furnace could generate high temperatures of up to $1200^{\circ} \mathrm{C}$ at a maximum heating rate of $30^{\circ} \mathrm{C} / \mathrm{min}$. The temperature level and the heating rate were programmable so that the testing systems could control the target temperature levels and ramp rates automatically. The furnace was insulated to guarantee that the temperature of the closed system inside of the furnace was that established by the program. A rectangular opening on 
172 the side of the furnace allowed two laser rays from the laser extensometer to measure the

173 elongation of the specimen. This opening could be closed in case the laser extensometer was

174 unused. To measure the loading level, a force sensor was placed outside the furnace to

175 measure and control the applied force. Six thermocouples were placed inside the furnace,

176 including three on the wall of the heating chamber and three on the sample surface, to follow

177 the temperature in real time and control the furnace accordingly.

178

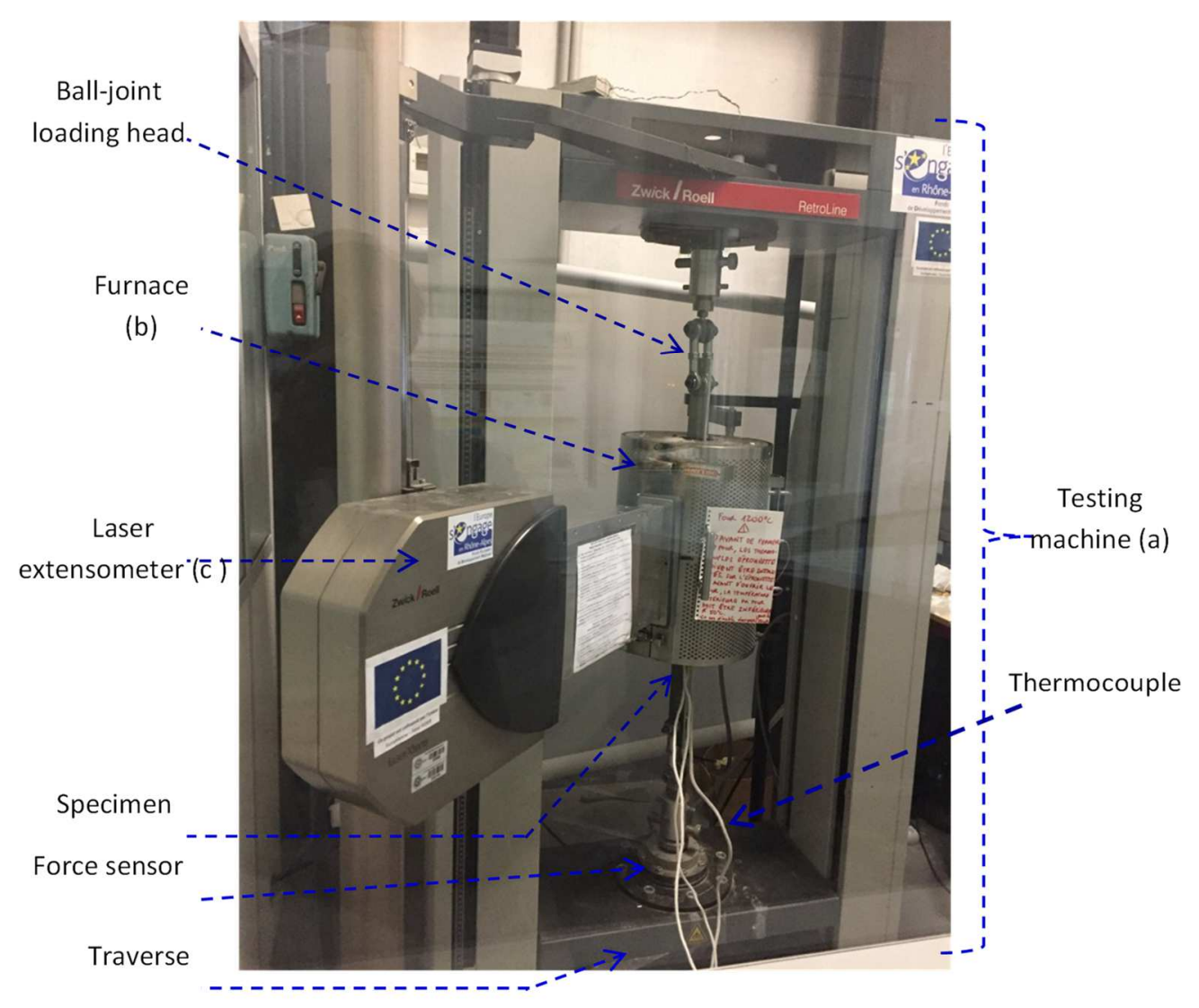

Figure 1. Thermo-mechanical testing system: a: mechanical machine; b: furnace; c: laser extensometer.

\subsection{Specimens}

In this research, the M-CFRP was prepared from unidirectional woven carbon fibres added to a polymer matrix. According to the supplier's datasheet, the carbon textile weighed $310 \mathrm{~g} / \mathrm{m}^{2}$ and had a thickness of $0.32 \mathrm{~mm}$, and the tensile strength of a carbon monofilament was $4902 \mathrm{MPa}$, with a tensile modulus of $230 \mathrm{GPa}$. The elongation failure of the carbon fibre was $2.1 \%$, and the minimum bond strength and shear strength of the polymer matrix were 14 
and $12 \mathrm{MPa}$, respectively; the elastic modulus of the polymer was $2 \mathrm{GPa}$ and its $\mathrm{Tg}$ was $40^{\circ} \mathrm{C}$, as specified in the supplier's datasheet. The carbon textile was first divided into test specimens that each contained four fibre rows, and aligned on a flat surface. The polymer matrix was prepared by mixing two components of epoxy following the recommended ratio and then brushed onto the textile, after which the polymer matrix was allowed to harden, forming mechanical and chemical bonds with the carbon fibres.

In most tensile testing procedures, the two ends of a sample are gripped by two clamps, and the tensile axial force is transmitted to the sample by the friction of the regions of contact between the clamps and the sample. However, the tensile strength of the material tested here was much greater than the friction force. Therefore, to transmit the tensile force from the mechanical components to the composite material effectively, two aluminium plates were attached to each end with an epoxy adhesive (Eponal 380). The shear resistance and tensile resistance of the epoxy were 15 and $29.5 \mathrm{MPa}$, respectively (from the supplier's datasheet). Figure 2 details the dimensions of the specimens tested without the insulation material (M-CFRP, Figure 2b) and with the insulation material (M-CFRP-Ins, Figure 2a).

The insulation's capacity for structural protection was first studied through a heat transfer test via a cylindrical sample (Figure 3), and then throughout an insulated CFRP specimen (Figure 2a). Five thermocouples (TC1 to TC5, Figure 3) were arranged inside and outside the sample to follow the temperature evolution at different positions on the specimen. The insulation material was non-combustible vermiculite/gypsum mortar (Tyfo® VG insulation). As indicated on the supplier's datasheet, the insulation's density was 0.458 $\mathrm{g} / \mathrm{cm}^{3}$; its compressive strength and bond strength were $0.893 \times 10^{-3}$ and $8.012 \times 10^{-5} \mathrm{MPa}$, respectively; its combustibility satisfies ASTM E136. 


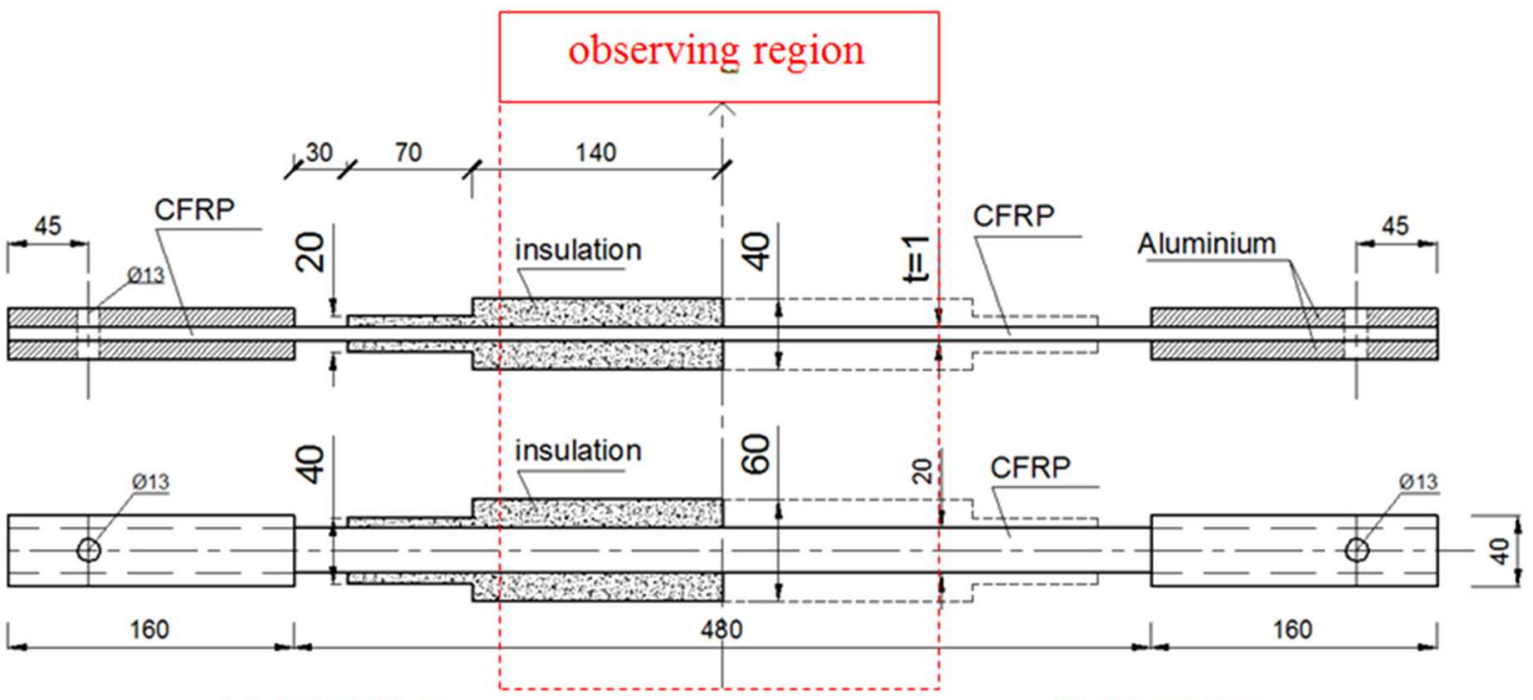

b) M-CFRP

Figure 2. Detail of sample.
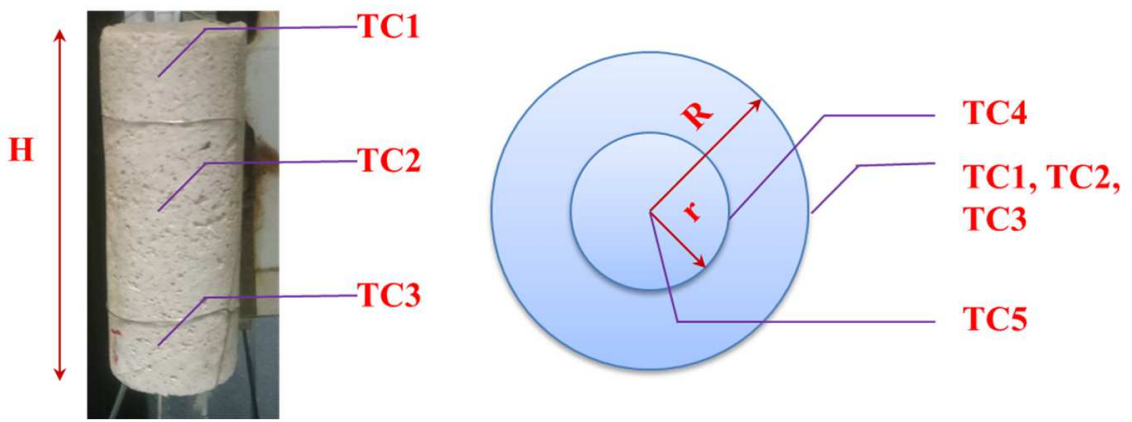

213 Figure 3. Cylindrical sample for testing the thermal resistance of the insulation material; $\mathrm{R}=38 \mathrm{~mm} ; \mathrm{r}=20 \mathrm{~mm}$;

$\mathrm{H}=200 \mathrm{~mm}$, with five thermocouple positions (TC1, TC2, TC3, TC4, TC5).

\subsection{Experimental procedures}

In this research, the M-CFRP and M-CFRP-Ins were tested following a

217 thermo-mechanical regime by which the failure temperature of the material could be

218 identified in relation to the imposed mechanical load. Following this regime, the specimen

219 was loaded with an applied force $\left(F_{w}\right)$ in the first phase (Figure 4$)$. In the second phase, while 220 maintaining $F_{w}$, the temperature surrounding the specimen was increased from room 221 temperature at the programmed ramp rate of $30^{\circ} \mathrm{C} / \mathrm{min}$ until the specimen ruptured. The 222 temperature at which the specimen broke was defined as the rupture temperature $\left(T_{r}\right)$ 223 corresponding to the $F_{w}$. The maximum duration that the material could maintain its required 
performance was defined as the exposure duration. The rupture temperature and exposure 225 duration were the two main factors employed to represent the thermo-mechanical performance of the specimens in the testing regime. Figure 5 details the heat transfer test conducted with the insulated cylindrical sample. In this test, the temperature surrounding the sample was increased from ambient temperature $\left(T_{a}\right)$ to $1100^{\circ} \mathrm{C}$ at a heating rate of $30^{\circ} \mathrm{C} / \mathrm{min}$. The performances of M-CFRP and M-CFRP-Ins are presented and discussed in 230 the following sections.

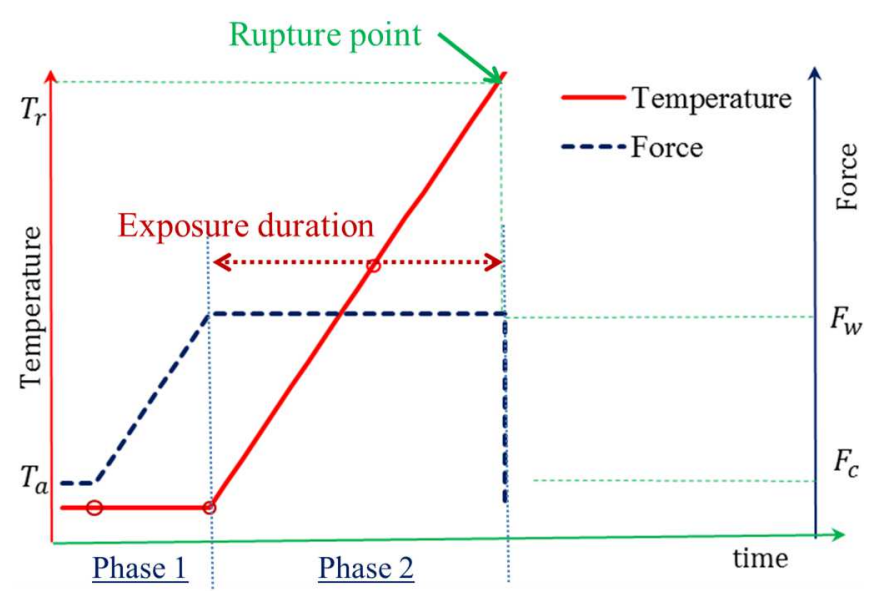

Figure 4. Thermo-mechanical testing regime; Ta: ambient temperature;

Tr: rupture temperature; Fc: control force; $\mathrm{F}_{\mathrm{w}}$ : applied force.

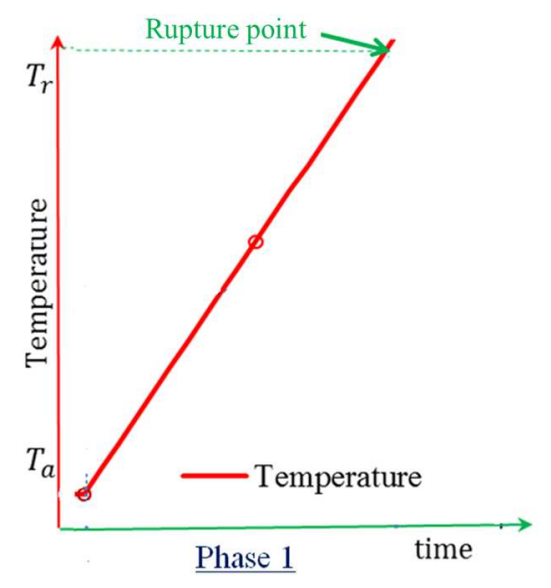

Figure 5. Thermal test with

insulation

\section{Experimental results and discussion}

Table 1 displays the ultimate strength and Young's modulus of the studied M-CFRP at room temperature. As can be seen in this table, the ultimate strength of this M-CFRP was between 816 and $1001 \mathrm{MPa}$, and its average measured Young's modulus was $62.2 \mathrm{GPa}$. These tensile properties were calculated based on the average dry dimensions (width and thickness) measured at every $5 \mathrm{~cm}$ along the specimen's length. The obtained ultimate strength was then used to identify the mechanical load to be applied on the M-CFRP material in the thermo-mechanical testing regime. 
Table 1. Properties of M-CFRP at room temperature.

\begin{tabular}{|l|c|c|c|c|}
\hline \multicolumn{1}{|c|}{ ID } & C.20.a & C.20.b & C.20.c & Average value \\
\hline Temperature $\left({ }^{\circ} \mathrm{C}\right)$ & 20 & 20 & 20 & 20 \\
\hline Ultimate stress (MPa) & 922.8 & 816.5 & 1001.3 & 913.5 \\
\hline Young's modulus (GPa) & 58.2 & 60.6 & 67.9 & 62.2 \\
\hline
\end{tabular}

242

Table 2 shows the thermo-mechanical performance of M-CFRP under different loading conditions in terms of the failure temperature (T_rup) and exposure duration. In this table, the applied load ratio $\left(f_{\mathrm{w}}\right)$ is identified as the ratio between the stress level that corresponds to the applied load and the average ultimate stress of the material obtained at $20^{\circ} \mathrm{C}$. These results show that when the applied load ratio $\left(f_{\mathrm{w}}\right)$ was less than 0.5 , the rupture temperature (T_rup) ranged between approximately $540^{\circ} \mathrm{C}$ and $650^{\circ} \mathrm{C}$, whereas the exposure duration varied from 20 to $52 \mathrm{~min}$. When $\mathrm{f}_{\mathrm{w}}$ was 0.75 , the T_rup was low, between $45^{\circ} \mathrm{C}$ and $64^{\circ} \mathrm{C}$, and the exposure duration was less than $3 \mathrm{~min}$.

Table 2. Thermo-mechanical performance of M-CFRP under different applied load ratios $\left(f_{w}\right)$.

\begin{tabular}{|c|c|c|c|c|c|c|c|c|c|c|c|}
\hline Sample ID & $\begin{array}{c}\text { C.T. } \\
\text { 010.a }\end{array}$ & $\begin{array}{c}\text { C.T. } \\
010 . \mathrm{b}\end{array}$ & $\begin{array}{c}\text { C.T. } \\
\text { 010.c }\end{array}$ & $\begin{array}{c}\text { C.T. } \\
\text { 025.a }\end{array}$ & $\begin{array}{c}\text { C.T. } \\
025 . \mathrm{b}\end{array}$ & $\begin{array}{c}\text { C.T. } \\
\text { 025.c }\end{array}$ & $\begin{array}{c}\text { C.T. } \\
\text { 050.a }\end{array}$ & $\begin{array}{c}\text { C.T. } \\
050 . \mathrm{b}\end{array}$ & $\begin{array}{c}\text { C.T. } \\
075 . \mathrm{a}\end{array}$ & $\begin{array}{c}\text { C.T. } \\
\text { 075.b }\end{array}$ & $\begin{array}{c}\text { C.T. } \\
075 . c\end{array}$ \\
\hline $\begin{array}{c}\text { Applied load } \\
\text { ratio, } \mathrm{f}_{\mathrm{w}}\end{array}$ & 0.1 & 0.1 & 0.1 & 0.25 & 0.25 & 0.25 & 0.5 & 0.5 & 0.75 & 0.75 & 0.75 \\
\hline \begin{tabular}{c} 
T_rup $\left({ }^{\circ} \mathrm{C}\right)$ \\
\hline $\begin{array}{c}\text { Exposure } \\
\text { duration } \\
\text { (minutes) }\end{array}$
\end{tabular} & 630 & 629 & 650 & 578 & 598 & 613 & 543 & 540 & 46 & 45 & 64 \\
\hline
\end{tabular}

The results obtained from M-CFRP-Ins under the thermo-mechanical testing regime are presented in Table 3. The table shows the exterior and interior temperatures (T_ex and T_in, respectively) of the insulation layer at the rupture point of the sample, as well as the exposure 
duration. Results were obtained for two cases of imposed load $\left(f_{w}=0.2\right.$ and $\left.f_{w}=0.3\right)$. The

257 rupture temperatures for the two loading cases were $780^{\circ} \mathrm{C}$ and $880^{\circ} \mathrm{C}$, respectively, and the exposure durations were 48 and $37 \mathrm{~min}$.

Table 3. Thermo-mechanical performance of M-CFRP-Ins.

\begin{tabular}{|c|c|c|c|}
\hline \multicolumn{2}{|c|}{ Sample ID } & C.T.020.Ins & C.T.030.Ins \\
\hline \multicolumn{2}{|c|}{ Applied load ratio, $\mathrm{f}_{\mathrm{w}}$} & 0.2 & 0.3 \\
\hline \multirow{2}{*}{ T_rup } & T_ex $\left({ }^{\circ} \mathrm{C}\right)$ & 780 & 880 \\
\cline { 2 - 4 } & T_in $\left({ }^{\circ} \mathrm{C}\right)$ & 867 & 688 \\
\hline \multirow{2}{*}{ Exposure duration (minutes) } & 47.93 & 36.58 \\
\hline
\end{tabular}

Figure 6 shows the temperature evolutions at the three different positions on the insulation material shown in Figure 3. At the beginning of the test, the exterior temperature increased from the initial condition with a ramp rate of $30^{\circ} \mathrm{C} / \mathrm{min}$, reaching $900^{\circ} \mathrm{C}$ in approximately $30 \mathrm{~min}$. Subsequently, this temperature continued to increase with a ramp rate of $4^{\circ} \mathrm{C} / \mathrm{min}$, reaching approximately $1100^{\circ} \mathrm{C}$ in $50 \mathrm{~min}$. In the first phase, the interior temperatures at TC4 (T_in_1) and TC5 (T_in_2) started to increase approximately 7 to 14 min later than the exterior temperatures, with ramp rates of $6.3^{\circ} \mathrm{C} / \mathrm{min}$ and $8.9^{\circ} \mathrm{C} / \mathrm{min}$, respectively. When the temperatures at TC4 and TC5 reached approximately $100^{\circ} \mathrm{C}$, there was a plateau phase in which the temperature increased only slightly with ramp rates of $1.3^{\circ} \mathrm{C} / \mathrm{min}$ and $0.4^{\circ} \mathrm{C} / \mathrm{min}$, respectively, in approximately 13 and $30 \mathrm{~min}$. In the final phase,

271 the temperature at TC4 increased steeply with a ramp rate of $23^{\circ} \mathrm{C} / \mathrm{min}$, whereas the corresponding rate at TC5 was $38^{\circ} \mathrm{C} / \mathrm{min}$. Subsequently, these two temperatures reached $273800^{\circ} \mathrm{C}$ in approximately 30 and $20 \mathrm{~min}$, respectively. The tests were terminated because of 274 safety considerations when these temperatures reached $1029^{\circ} \mathrm{C}$ and $1007^{\circ} \mathrm{C}$. 


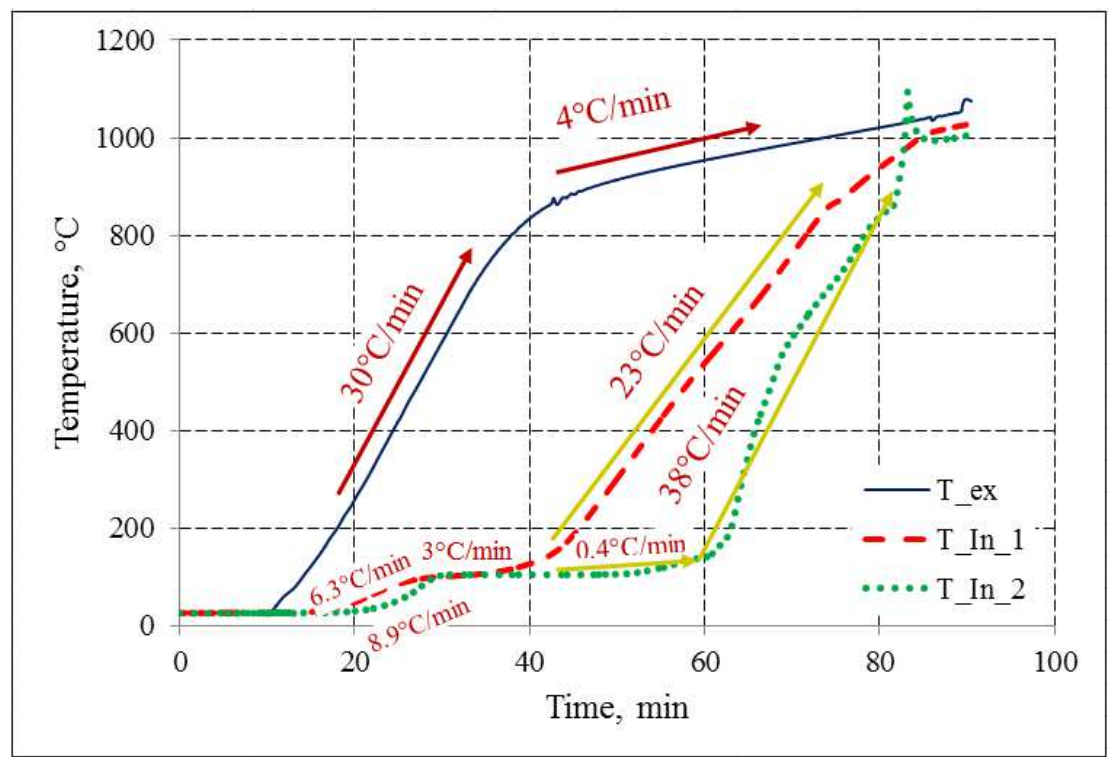

276 Figure 6. Evolution of exterior $\left(\mathrm{T} \_\right.$ex $)$and interior $\left(\mathrm{T}_{-}\right.$in_1; $\mathrm{T} \_$in_2) temperatures of the insulation material during heat transfer tests (thermocouple positions are shown in Figure 3).

Figures 7 and 8 show the temperature evolutions at the exterior and interior of the insulation material during the thermo-mechanical tests for the two loading cases. When the applied load ratio was 0.2 (the corresponding imposed load was $2317 \mathrm{~N}$ ), the actual exterior temperature increased from room temperature (approximately $20^{\circ} \mathrm{C}$ ) with a ramp rate of $28^{\circ} \mathrm{C} / \mathrm{min}$ and reached $600^{\circ} \mathrm{C}$ in approximately $20 \mathrm{~min}$ (Figure 7). Subsequently, the ramp rate decreased until the M-CFRP-Ins ruptured. The evolution of the interior temperature also exhibited three distinct phases: in the first phase, the temperature gradually increased from the initial temperature to $95^{\circ} \mathrm{C}$ with a ramp rate of $11^{\circ} \mathrm{C} / \mathrm{min}$. This phase occurred over approximately $5 \mathrm{~min}$. In the second phase, the interior temperature slightly increased with a ramp rate of $0.65^{\circ} \mathrm{C} / \mathrm{min}$ for more than $10 \mathrm{~min}$ before rapidly increasing with a ramp rate of approximately $40^{\circ} \mathrm{C} / \mathrm{min}$ in the third phase. With an applied load ratio of 0.3 (corresponding

289 to an imposed load of $3476 \mathrm{~N}$ ), the exterior temperature increased with a ramp rate of $24.5^{\circ} \mathrm{C} / \mathrm{min}$ and reached $600^{\circ} \mathrm{C}$ in approximately $20 \mathrm{~min}$ (Figure 8). The increase in the

291 interior temperature also exhibited distinct phases. In the first phase, the temperature 292 gradually increased for approximately $5 \mathrm{~min}$ from the initial temperature to approximately 
$94^{\circ} \mathrm{C}$. In the second phase, the temperature slightly increased with a ramp rate of $0.95^{\circ} \mathrm{C} / \mathrm{min}$

294 over approximately $15 \mathrm{~min}$ before steeply increasing at a ramp rate of $58^{\circ} \mathrm{C} / \mathrm{min}$ until rupture.

295

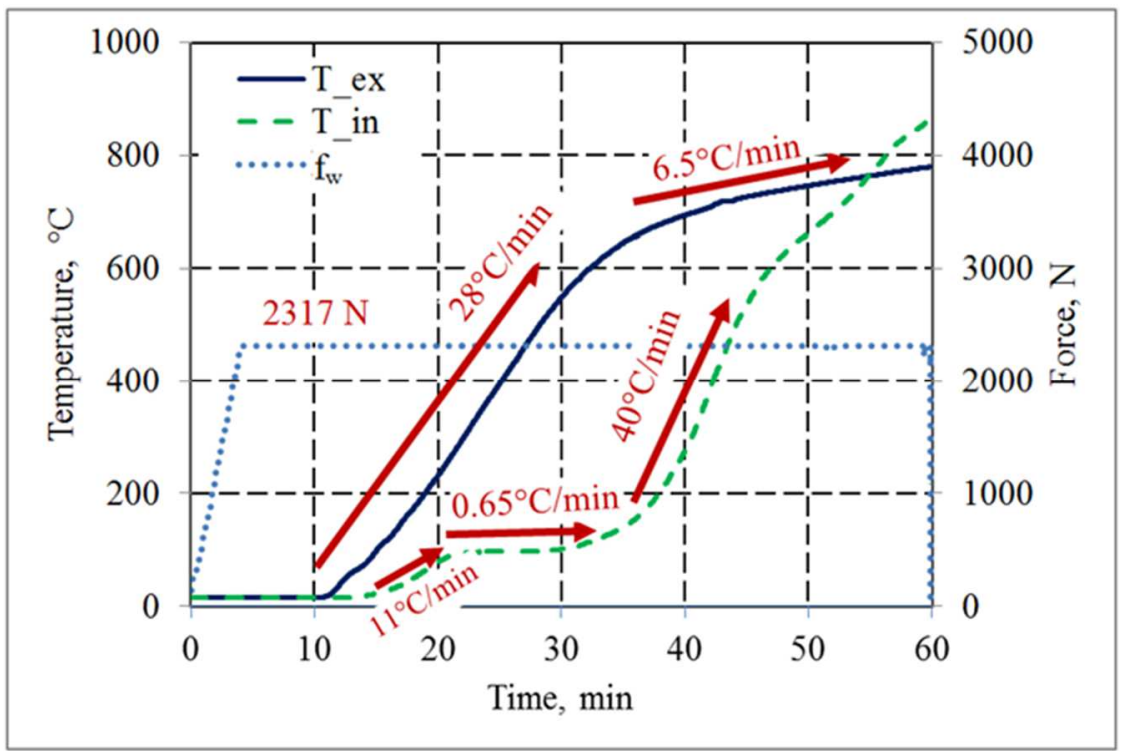

Figure 7. Evolution of external and internal temperatures of M-CFRP-Ins with an applied load ratio $\left(f_{w}\right)$ of $20 \%$

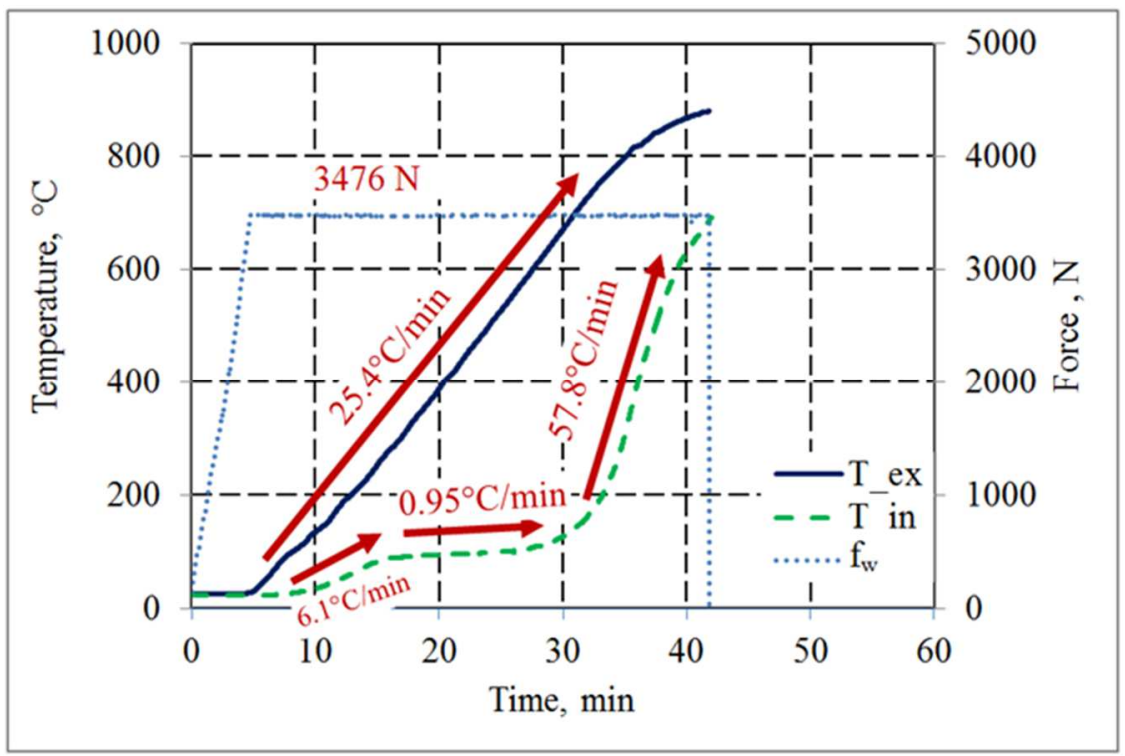

Figure 8. Evolution of external and internal temperatures of M-CFRP-Ins with an applied load ratio $\left(\mathrm{f}_{\mathrm{w}}\right)$ of $30 \%$.

The temperature increase exhibited by M-CFRP-Ins (Figures 6, 7 and 8) was stable at approximately $25.4^{\circ} \mathrm{C} / \mathrm{min}$ to $30^{\circ} \mathrm{C} / \mathrm{min}$ until reaching approximately $600^{\circ} \mathrm{C}-800^{\circ} \mathrm{C}$, whereas the actual heating rate inside the furnace significantly decreased from $4^{\circ} \mathrm{C} / \mathrm{min}$ to $6.5^{\circ} \mathrm{C} / \mathrm{min}$, depending on the test case, because of the homogeneous temperature requirement. This may explain why, at the same mechanical load ratio of 0.25 , the specimen 
C.T.025.b failed at $598^{\circ} \mathrm{C}$ after $25.7 \mathrm{~min}$, whereas the specimen C.T.025.c failed at $613^{\circ} \mathrm{C}$ after $20.1 \mathrm{~min}$ (Table 2).

According to the obtained results, the rupture temperature of M-CFRP decreased as the applied load increased. Figures 9 and 10 show the evolution of the rupture temperature and thermal exposure duration of M-CFRP as the imposed load increased (M-CFRP.T2 and M-CFRP.T2.Avg). When the applied load ratio increased from 0.1 to 0.25 (or to 0.5 ), the rupture temperature gradually decreased from $636^{\circ} \mathrm{C}$ to $596^{\circ} \mathrm{C}$ (or to $541^{\circ} \mathrm{C}$ ) (on average), and the exposure duration varied from $33 \mathrm{~min}$ to $23 \mathrm{~min}$ (or to $30 \mathrm{~min}$ ), respectively. When the applied load ratio increased to 0.75 , the rupture temperature significantly decreased to $52^{\circ} \mathrm{C}$, and the exposure duration decreased to $1 \mathrm{~min}$ (on average). The heat transfer test on M-CFRP-Ins showed that in the radial direction, the temperature evolution was delayed in conjunction with the thickness of the insulation layer (Figure 6). The evolution of the interior temperature of the insulation material clearly exhibited three distinct phases.

The results also showed that the thermo-mechanical performance of M-CFRP-Ins varied under different mechanical loading conditions (M-CFRP.T2-Ins, Figure 9 and Figure 10). In particular, the temperature of the M-CFRP-Ins increased approximately $150^{\circ} \mathrm{C}$ at $\mathrm{f}_{\mathrm{w}}=0.2$ and approximately $300^{\circ} \mathrm{C}$ at $\mathrm{f}_{\mathrm{w}}=0.3$ (Figure 9). Likewise, the exposure duration increased more than $20 \min$ for $f_{w}=0.2$ and more than $15 \min$ for $f_{w}=0.3$. These results showed that the exterior temperatures at failure were higher than the failure temperatures of the uninsulated materials (Figure 9). The interior temperatures at failure of these test cases were also higher than those of the uninsulated cases. As can be interpolated from Figure 9, at $\mathrm{f}_{\mathrm{w}}=0.2$, the interior temperature at failure of the insulated specimen was approximately $750^{\circ} \mathrm{C}$, compared to approximately $610^{\circ} \mathrm{C}$ for the uninsulated specimen; at $\mathrm{f}_{\mathrm{w}}=0.3$, the interior temperature at 327 failure was approximately $687^{\circ} \mathrm{C}$, compared to approximately $570^{\circ} \mathrm{C}$ for the uninsulated 328 specimen. 


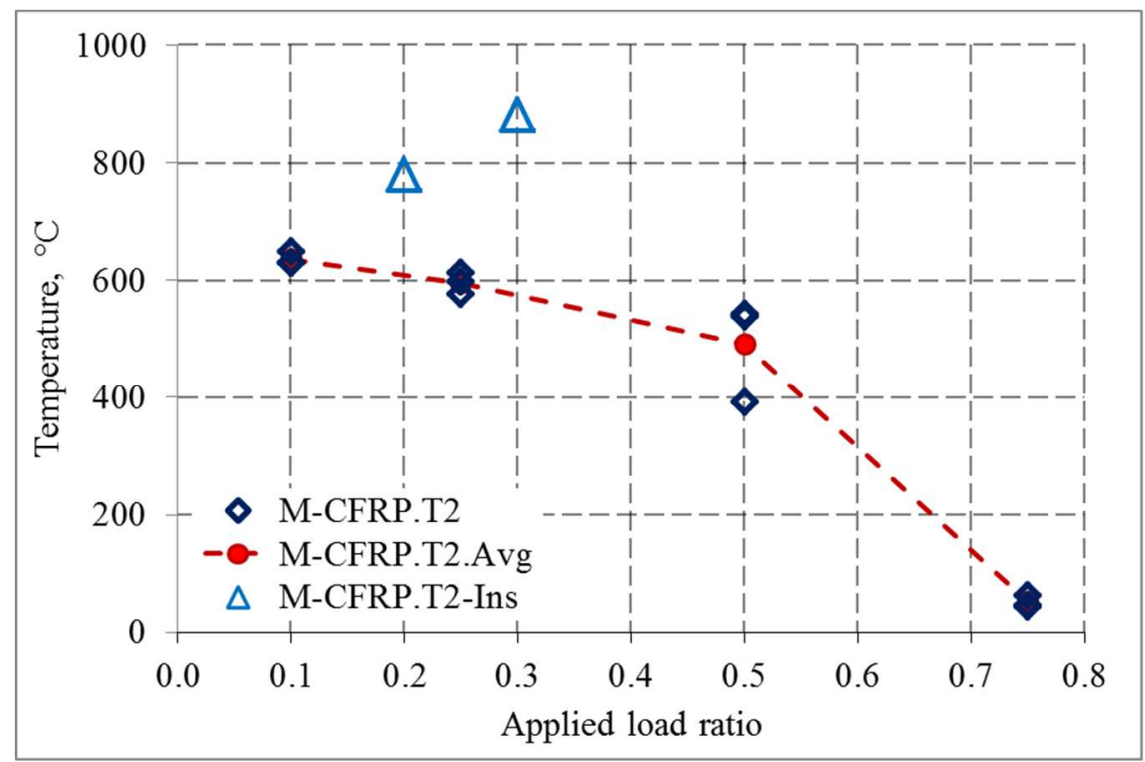

Figure 9. Failure temperature of M-CFRP at different applied load ratios $\left(f_{w}\right)$.

331 In the two insulated cases, the temperature ramp rates on the M-CFRP surface were 332 approximately $40^{\circ} \mathrm{C} / \mathrm{min}$ and $57.8^{\circ} \mathrm{C} / \min$ (Figure 7 and Figure 8), higher than the heating 333 rates on the insulation surface, which were approximately $28^{\circ} \mathrm{C} / \mathrm{min}$ and $25.4^{\circ} \mathrm{C} / \mathrm{min}$ 334 respectively. These results reflect the lower mass loss rate of epoxy resin at higher heating rates from $10^{\circ} \mathrm{C} / \mathrm{min}$ to $40^{\circ} \mathrm{C} / \mathrm{min}[30,37]$. In the insulated cases, the direct contact between 336 oxygen, the epoxy matrix and carbon fibres at high temperatures was very limited, whereas 337 without insulation, the presence of oxygen in the heating chamber could accelerate the 338 ignition of carbon fibres [50]. 


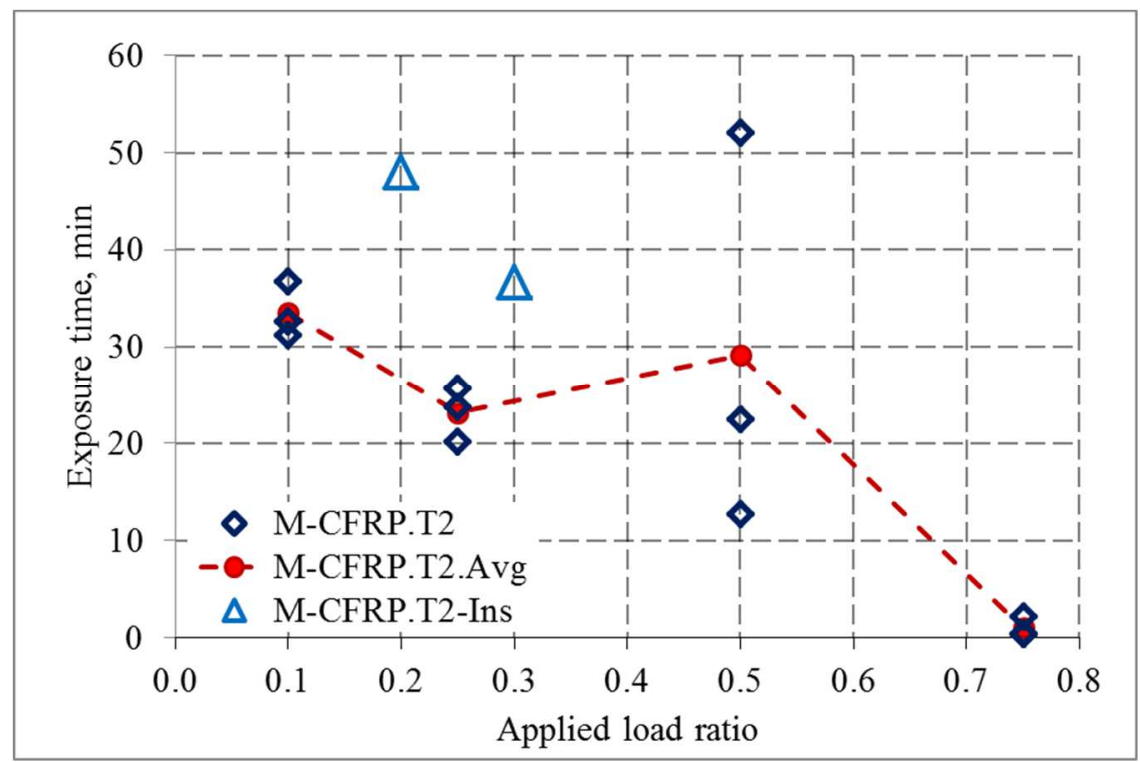

Figure 10. Exposure time of M-CFRP at different applied load ratios $\left(f_{w}\right)$.

\section{Finite element modelling}

A finite element modelling was investigated to study the efficiency of the insulation material under different temperature conditions. A previously developed heat transfer model for predicting temperature in an insulated concrete section with a finite-volume code was applied. The partial differential equation of heat conduction was expressed as:

$$
\rho c \frac{\partial T}{\partial t}=\nabla \cdot(k \nabla T)=\frac{\partial}{\partial x}\left(k_{x} \frac{\partial T}{\partial x}\right)+\frac{\partial}{\partial y}\left(k_{y} \frac{\partial T}{\partial y}\right)+\frac{\partial}{\partial z}\left(k_{z} \frac{\partial T}{\partial z}\right)
$$

Where: $T$ is temperature, $t$ is time, $k$ is thermal conductivity, $\rho$ is density and $c$ is heat capacity.

\subsection{Numerical model}

The experimental insulation material, as shown in Figure 2, had a length of $280 \mathrm{~mm}$, width of $60 \mathrm{~mm}$, and thickness of $40 \mathrm{~mm}$. Because of the symmetrical loading and boundary conditions, a one-eighth model was generated and analysed using the finite element code ANSYS APDL (Figure 11). The finite element model of the insulation material had a length of $140 \mathrm{~mm}$, width of $30 \mathrm{~mm}$, and thickness of $20 \mathrm{~mm}$. The one-eighth model can simplify the 
computation process by reducing the number of elements while maintaining the reliability of

356 the analysis. The element type chosen for the transient thermal analysis was SOLID70 (a 3D

357 8-node thermal solid), as shown in Figure 12. With a maximum meshing element size of 2

$358 \mathrm{~mm}$, there were 11852 elements for the numerical calculations conducted to simulate the 359 experimental tests.

Figure 11. One-eighth symmetry finite element model with meshed elements during heating.
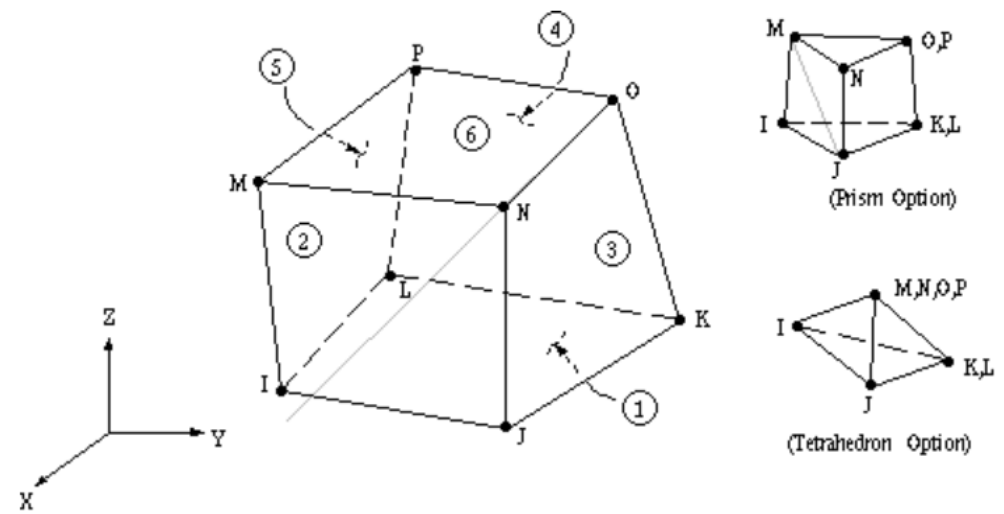

Figure 12. SOLID70 : 3D 8-node thermal solid [51]; 8 nodes of the element SOLID 70: I, J, L, K, O, N, M, P; key numbers from 1 to $6: 6$ faces of the element SOLID 70: 1 (J-I-L-K), 2 (I-J-N-M), 3 (J-K-O-N), 4 properties at $20^{\circ} \mathrm{C}$ were adopted from previously published studies on the same insulation 
type [36]: thermal conductivity, $\mathrm{K}_{0}=2.5 \times 10^{-4} \mathrm{~W} / \mathrm{mm} \cdot \mathrm{K}$; specific heat, $\mathrm{C}_{0}=1654 \mathrm{~J} / \mathrm{kg} \cdot \mathrm{K}$; and

371 density, $\rho_{0}=2.69 \times 10^{-7} \mathrm{~kg} / \mathrm{mm}^{3}$. The evolution of the insulation material's thermal properties

372 in relation to temperature is summarized by Hawileh et al. [36] (see Table 4).

Table 4. Evolution of normalized thermal properties of the insulation material [36].

\begin{tabular}{|l|l|l|l|l|l|l|l|l|l|}
\hline Temperature $\left({ }^{\circ} \mathrm{C}\right)$ & 20 & 100 & 150 & 200 & 300 & 400 & 500 & 600 & 700 \\
\hline $\begin{array}{l}\text { Normalized specific } \\
\text { heat } \mathrm{C} / \mathrm{C}_{0}\left(20^{\circ} \mathrm{C}\right)\end{array}$ & 1.00 & 3.60 & 0.80 & 0.55 & 0.55 & 0.50 & 0.45 & 0.45 & 0.45 \\
\hline $\begin{array}{l}\text { Normalized thermal } \\
\text { conductivity } \mathrm{K} / \mathrm{K}_{0}\left(20^{\circ} \mathrm{C}\right)\end{array}$ & 1.00 & 1.00 & 0.45 & 0.45 & 0.45 & 0.50 & 0.60 & 0.80 & 0.80 \\
\hline
\end{tabular}

The evolution of the exterior temperature condition was modelled following the temperature evolution in the experimental tests (Figure 7 and Figure 8). In this process, three cases of transient heat transfer were observed: two cases simulated two of the experimental temperature conditions applied to M-CFRP-Ins, and the third case extended the model to the fire-temperature condition.

\subsection{Numerical results}

To examine the validity of the model, the finite element model and experimental results

382 were compared. Figure 13 shows the temperature distribution in the insulation volume of the C.T.020.Ins case (see Table 3). Figures 14 and 15 show the temperature evolutions of the exterior temperature (T_ext.-) and the interior temperature (T-int.-) obtained numerically (-.N) and experimentally (-.E) for the two cases C.T.020.Ins and C.T.030.Ins (see Table 3).

The exterior point was located on the middle of the surface of the insulation volume and the

387 interior point was located on the middle of the interface between the CFRP material and the 388 insulation material (measured by thermocouple in the experiment, Figure 2). In the numerical 
390 (corresponding to the position of thermocouple in the experiment).

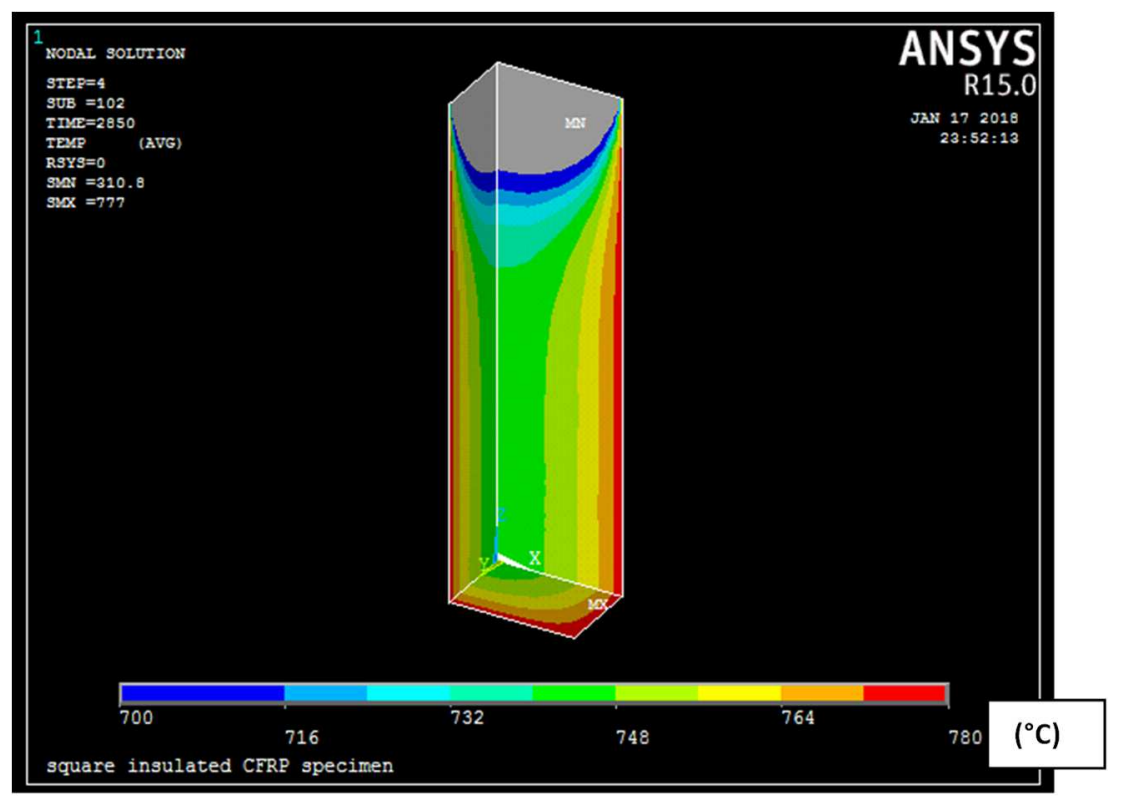

Figure 13. Temperature distribution of the C.T.020.Ins case $\left({ }^{\circ} \mathrm{C}\right)$.

As can be seen from Figures 14 and 15, the exterior temperatures obtained with the 394 numerical model were generated according to the exterior temperatures obtained in the 395 experiments. The predicted interior temperatures for the two cases were very close to the 396 results obtained in the experiments. In the C.T.020.Ins case, the experimental interior 397 temperature rapidly increased; the numerical values were close but still lower than the 398 exterior temperature. The numerical model did not include a mechanical load, and the 399 insulation material was assumed to be continuous and isotropic, whereas in the experiments, 400 the material was subjected to mechanical loading, which may have influenced the 401 performance of the insulation material. 


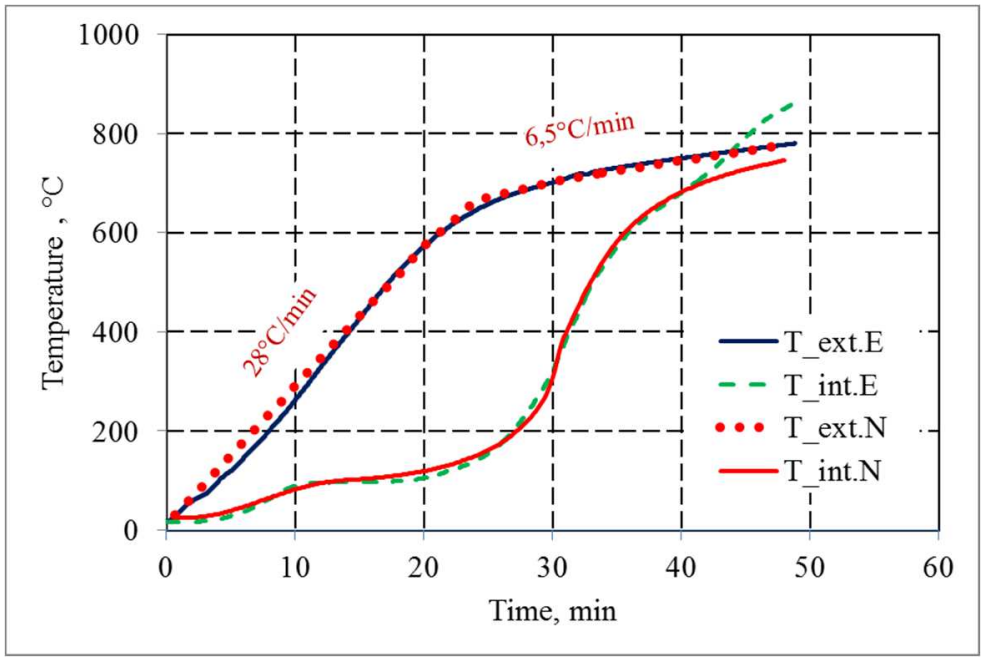

Figure 14. Temperature evolution of exterior temperature (T_ext.-) and interior temperature (T-int.-) of

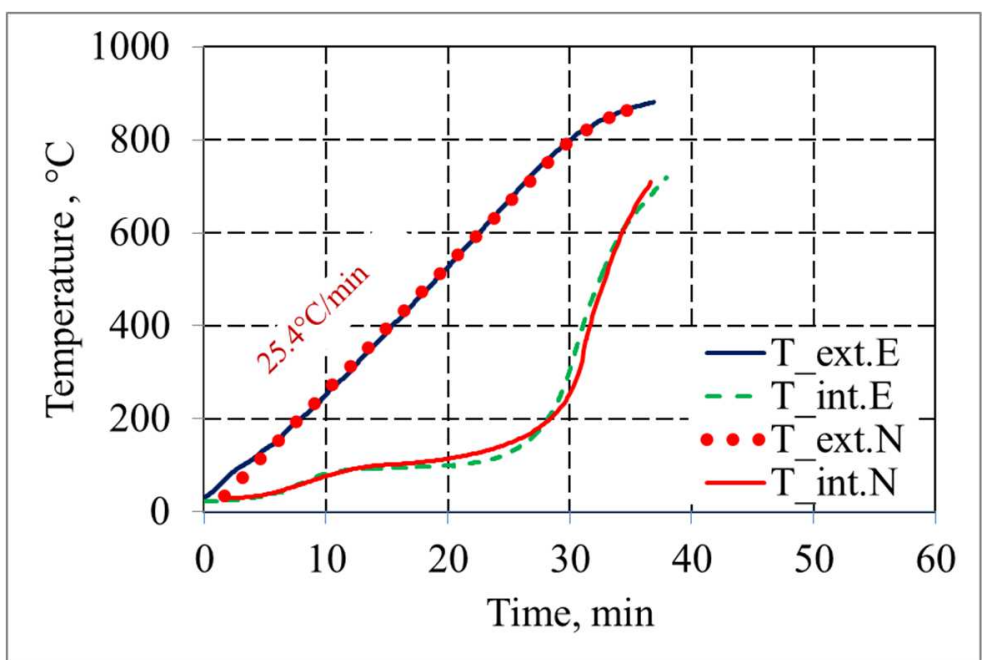

Figure 15. Temperature evolution of exterior temperature (T_ext.-) and interior temperature (T-int.-) of C.T.030.Ins case: numerical result (-.N) and experimental result (-.E).

From the successful calibration of the input thermal properties based on the two

410 experimental tests, a third model was generated to observe the insulation material's capacity

411 to protect CFRP under a temperature condition that approximates that of an actual fire. The

412 third thermal analysis model had the same material properties; however, the geometry varied 413 in terms of the thickness of the insulation layer, from 1 to $5 \mathrm{~cm}$, as shown in Table 5 . The 414 model was then applied to simulate a thermal load on the insulation surface with a 415 temperature evolution in accordance with the standard fire curve specified in ISO-834 [52]. 
416 Figure 16 displays the evolution of the exterior and interior temperatures as a function of time

417 in different cases. As can be seen from Figure 16, the temperature applied on the specimen's 418 surface (N.T_ext-ISO 834 curve) in the model was exactly equal to the standard fire curve 419 (standard ISO 834 curve). The interior temperature curves for the different thicknesses 420 (N.T_int.Xcm, with $X$ from 1 to $5 \mathrm{~cm}$ ) showed that the thicker the insulation material, the 421 longer that the heat conduction was delayed.

Table 5. Geometry of the fire-testing model (one-eighth model).

\begin{tabular}{|l|l|l|l|l|l|l|}
\hline \multicolumn{2}{|l|}{ Thickness of insulation layer, cm } & 1 & 2 & 3 & 4 & 5 \\
\hline \multirow{2}{*}{ Specimen } & Length & 14 & 14 & 14 & 14 & 14 \\
\cline { 2 - 7 } dimension, cm & Width & 2 & 3 & 4 & 5 & 6 \\
\cline { 2 - 7 } & Thickness & 1 & 2 & 3 & 4 & 5 \\
\hline
\end{tabular}

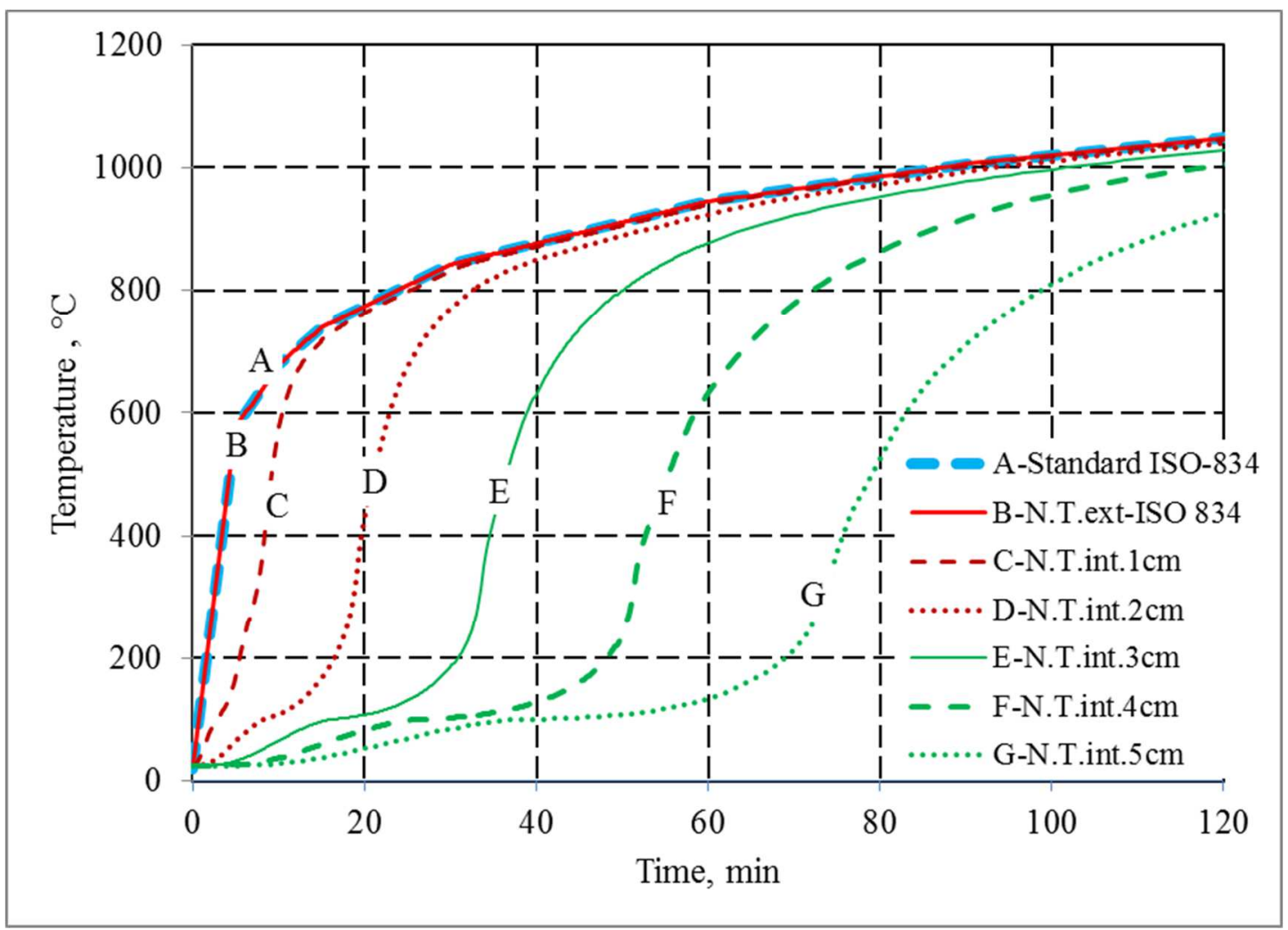

Figure 16. Exterior and interior temperature evolution of insulation volumes with different thicknesses under standard fire-temperature condition. 
Table 6 summarizes the average failure temperature of M-CFRP under different applied load ratios. According to this summary, when the applied load ratio increased from 0.1 to 0.5 , the failure temperature gradually decreased from $636.4^{\circ} \mathrm{C}$ to $491.8^{\circ} \mathrm{C}$. At the load ratio of 0.75 , the failure temperature significantly decreased to $51.7^{\circ} \mathrm{C}$.

Table 6. Thermal resistance of M-CFRP under different applied load ratios.

\begin{tabular}{|l|l|l|l|l|}
\hline Applied load ratio & 0.1 & 0.25 & 0.5 & 0.75 \\
\hline Average rupture temperature, ${ }^{\circ} \mathrm{C}$ & 636.4 & 596.3 & 491.8 & 51.7 \\
\hline
\end{tabular}

Although the results from the M-CFRP-Ins tests showed that at the time of failure, the temperature of M-CFRP-Ins was higher than that of M-CFRP, further experiments and analysis need to be undertaken to confirm this tendency. In civil engineering, when a fire occurs, there are several phenomena that must be considered: structures are subjected to service loads, temperatures are elevated, chemical reactions or degradation of the material occurs, and there is toxic smoke. This research focused on the performance of M-CFRP and M-CFRP-Ins under combined elevated temperature and mechanical loading conditions, 441 without considering other phenomena, such as material degradation due to elevated temperature. According to current guidelines for fire safety designs, the main role of the insulation material is to protect the structure under elevated temperatures. Furthermore, the 444 mechanical properties of several commercially available insulation materials are not 445 significant in comparison with the corresponding properties of the structure and construction materials. The results presented here can be applied to predict the performance of M-CFRP under combined mechanical and temperature loads in case of fire. Furthermore, the 
experimental and numerical results can be applied to estimate the temperature evolution

449 behind insulation layers with certain thicknesses at different elevated temperatures. The experimental M-CFRP-Ins results showed that the real temperature at the M-CFRP surface

451 (under the insulation layer) at failure was higher than that of without the insulation material.

452 However, if the failure temperature in the case without the insulation material is defined as a

453 failure criterion for M-CFRP, then it is possible to apply this criterion to predict the failure of 454 insulated M-CFRP specimens that are simultaneously subjected to both mechanical loading 455 and elevated temperature. Therefore, within the scope of this research, the surface temperatures of M-CFRP at failure in the two tested cases (with and without insulation material) are not significantly different, disregarding the mechanical status. Based on the numerical result for the fire-temperature loading case (Figure 16), a thickness of insulation material can be proposed to protect the M-CFRP under such temperatures, with regard for the mechanical loading status and the required exposure duration, as displayed in Figure 17.

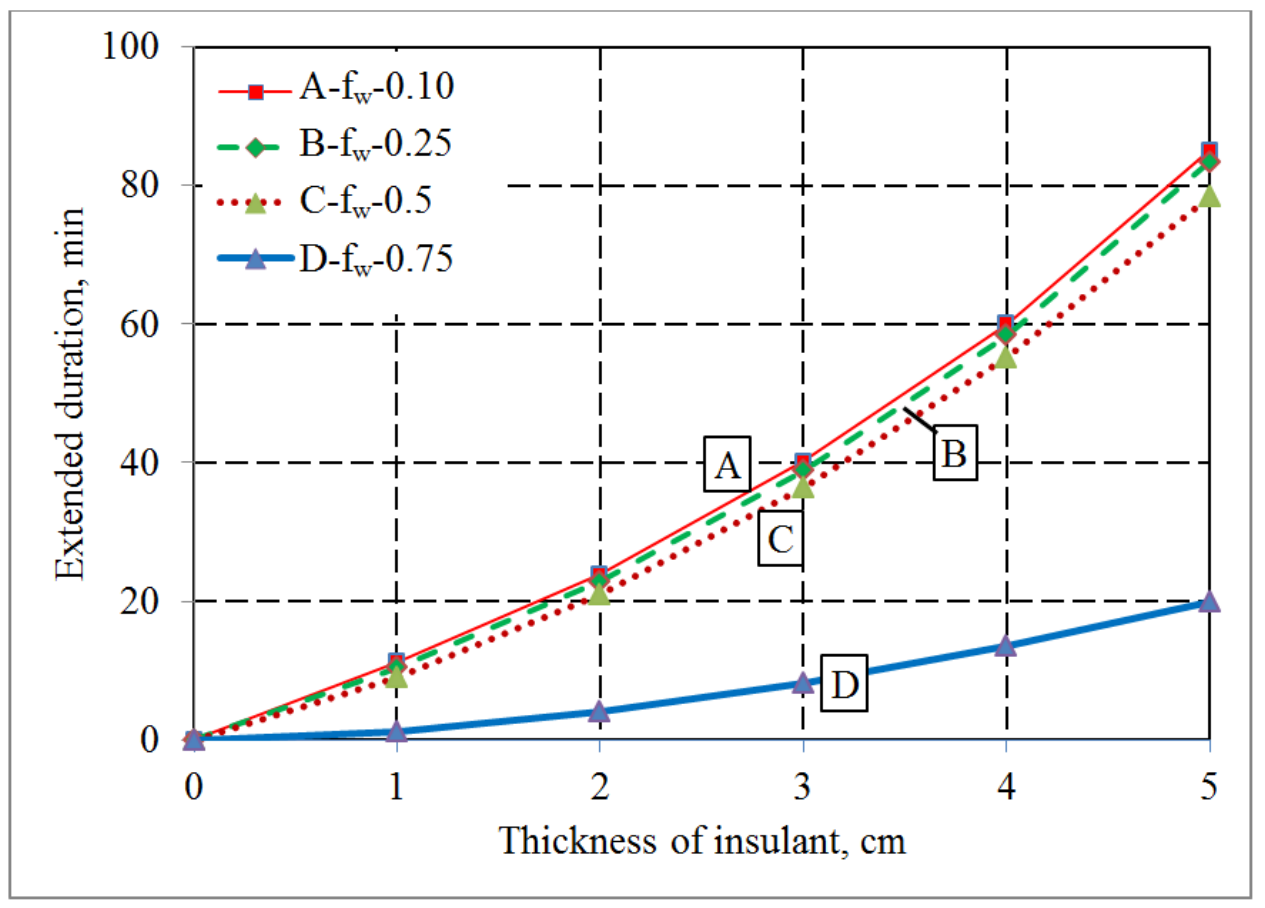

Figure 17. Extended fire performance of M-CFRP based on different thickness of insulation layer.

From a civil engineering perspective, if M-CFRP is subjected to a mechanical load up to $46450 \%$ of the material's resistance capacity, an insulation material with a thickness of 
approximately $4.3 \mathrm{~cm}$ can protect the M-CFRP under fire-temperature conditions for up to 60 $\min ($ Figure 17).

\section{Conclusions}

This work aimed to investigate the performance of M-CFRP and M-CFRP-Ins using a thermo-mechanical testing regime. When the imposed load increased, the maximum temperature to which the M-CFRP could be exposed decreased. When the imposed load was less than $50 \%$ of its strength at $20^{\circ} \mathrm{C}$, the rupture temperature decreased slightly, from $636^{\circ} \mathrm{C}$ to $541^{\circ} \mathrm{C}$, on average. When subjected to a load level equal to $75 \%$ of its strength at $20^{\circ} \mathrm{C}$, the rupture temperature of $\mathrm{M}$-CFRP sharply decreased to $52^{\circ} \mathrm{C}$ on average. The use of an insulation material was shown to improve the thermo-mechanical performance of M-CFRP in the tested regime. The thermal-delay capacity depended on the thickness of the insulation layer. With $2 \mathrm{~cm}$ of insulation thickness, the heat penetration to the M-CFRP surface was delayed by approximately $10 \mathrm{~min}$ (under the tested conditions). In this testing regime, the M-CFRP-Ins could be exposed to higher temperatures for longer durations because of the reduced contact between CFRP and oxygen. The numerical results showed that, under fire-temperature conditions, the insulation could protect M-CFRP to satisfy fire design requirements in terms of exposure duration, depending on the mechanical status of the M-CFRP material.

\section{Acknowledgments}

This research was performed with the financial support of the industrial projects program of LMC2, as well as a doctoral scholarship from the Ministry of Education and Training of Vietnam for the first author. We would like to thank Fibrwrap Construction, Inc. (Villeurbanne, France) for the supply of the materials used in this study. We would like also 
to thank the team of technicians from the LMC2 and the Civil Engineering Department of

\section{References}

1. Wang, Y. C.; Wong, P. M. H.; Kodur, V. An experimental study of the mechanical properties of fibre reinforced polymer (FRP) and steel reinforcing bars at elevated temperatures. Compos. Struct. 2007, 80 (1), $131-140$.

2. Wang, K.; Young, B.; Smith, S. T. Mechanical properties of pultruded carbon fibre-reinforced polymer (CFRP) plates at elevated temperatures. Eng. Struct. 2011, 33 (7), 2154-2161.

3. Yu, B.; Kodur V. K. R. Effect of temperature on strength and stiffness properties of near-surface mounted FRP reinforcement. Compos. Part B Eng. 2014, 58, 510-517.

4. Cao, S.; Wu, Z.; Wang X. Tensile properties of CFRP and hybrid FRP composites at elevated temperatures. J. Compos. Mater. 2009, 43 (4), 315-330.

5. Cree, D.; Gamaniouk, T.; Loong, M.L.; Green, M.F. Tensile and lap-splice shear strength properties of CFRP composites at high temperatures. J. Compos. Constr. 2015: 19.

6. Nguyen P. L., Vu X. H., and Ferrier E., "Elevated temperature behaviour of carbon fibre-reinforced polymer applied by hand lay-up (M-CFRP) under simultaneous thermal and mechanical loadings: Experimental and analytical investigation,” Fire Saf. J., vol. 100, pp. 103-117, Sep. 2018.

7. Foster, S. K.; Bisby, L. A. Fire survivability of externally bonded FRP strengthening systems. J. Compos. Constr. 2008, 12 (5), 553-561.

507 8. Mouritz, A. P.; Gibson, A. G. Fire properties of polymer composite materials. 2006, vol. 143. Dordrecht: 508 Springer, Netherlands.

509 9. Correia, J. R.; Branco, F. A.; Ferreira, J. G.; Bai, Y.; Keller, T. Fire protection systems for building floors made of pultruded GFRP profiles part 1: experimental investigations. Compos. Part B Eng. 2010, 41 (8), $617-629$.

10. Bisby, L. A.; Green M. F.; Kodur V. K. R. Response to fire of concrete structures that incorporate FRP. Prog. Struct. Eng. Mater. 2005, 7 (3), 136-149. 
11. Reddy, D. V.; Sobhan, K.; Young, J. Effect of fire on structural elements retrofitted by carbon fiber reinforced polymer composites. $31^{\text {st }}$ Conference on Our World Concrete and Structure, 2006, 16-17.

516 12. Turkowski, P.; Łukomski, M.; Sulik, P.; Roszkowski P. Fire resistance of CFRP-strengthened reinforced 517 concrete beams under various load levels. Procedia Eng. 2017, 172, 1176-1183.

518 13. Al-Abdwais A.; Al-Mahaidi R.; Al-Tamimi A. Performance of NSM CFRP strengthened concrete using modified cement-based adhesive at elevated temperature. Constr. Build. Mater. 2017, 132, 296-302.

14. Firmo, J. P.; Arruda, M. R. T.; Correia, J. R. Contribution to the understanding of the mechanical behaviour of CFRP-strengthened RC beams subjected to fire: experimental and numerical assessment. Compos. Part B Eng. 2014, 66, 15-24.

15. Adelzadeh, M.; Hajiloo, H.; Green, M. F. Numerical study of FRP reinforced concrete slabs at elevated temperature. Polymers 2014, 6 (2), 408-422.

16. Hajiloo, H.; Green, M. F.; Noël, M.; Bénichou, N.; Sultan, M. Fire tests on full-scale FRP reinforced concrete slabs. Compos. Struct. 2017, 179, 705-719.

17. Yuqian, Z. Performance of FRP-strengthened beams subjected to elevated temperatures. Ph.D. thesis dissertation for the National University of Singapore, Singapore, 2010.

18. ASTM. ASTM E119: Omega Point Lab Fire Blocking Test, Aug. 2002.

19. Tan, K. H.; Zhou, Y. Q. Basalt FRP laminates subjected to elevated temperatures. Proceeding of the 3rd ACF International Conference (ACF/VCA - 2008), Hochiminh City, Vietnam, 2008, 137-143.

20. Tan, K. H.; Zhou, Y. Q. Basalt FRP-strengthened beams subjected to elevated temperatures. The 2nd International Workshop on Performance: Protection and Strengthening of Structures under Extreme Loading (PROTECT 2009), Shonan Village Center, Hayama, Japan, 2009.

21. Tan, K. H.; Zhou, Y. Q. Fiber-reinforced cement composites under elevated temperatures. Proceedings of the 5th International RILEM Workshop, Mainz, Germany, 2007, 371-377.

22. Terrasi, G. P.; Bisby, L.; Barbezat, M.; Affolter, C.; Hugi, E. Fire behavior of thin CFRP pretensioned high-strength concrete slabs, J. Compos. Constr. 2012, 16 (4), 381-394.

23. Maluk, C.; Bisby, L.; Terrasi, G. Bond strength degradation for pre-stressed steel and carbon FRP bars in high-performance self-consolidating concrete at elevated temperatures and in fire. 6th International $541 \quad$ Conference on Structures in Fire (SiF 2010), East Lansing, Michigan, USA, 2010. 
24. Thomas P. H. Design guide: structure fire safety CIB W14 workshop report. Fire Saf. J. 1986, 10 (2), 77 137.

25. Green, M. F.; Bénichou, N.; Kodur, V. K. R.; Bisby, L. A. Design guidelines for fire resistance of FRP-strengthened concrete structures. Proceeding of the Eighth International Conference on FRP in Reinforced Concrete Structures (FRPRCS-8), Patras, Greece, July 2007, 16-18.

26. Firmo, J. P.; Correia, J. R.; França, P. Fire behaviour of reinforced concrete beams strengthened with CFRP laminates: protection systems with insulation of the anchorage zones. Compos. Part B Eng. 2012, 43(3), $1545-1556$.

27. Firmo, J. P.; Correia, J. R. Fire behaviour of thermally insulated RC beams strengthened with EBR-CFRP strips: experimental study. Compos. Struct. 2015, 122, 144-154.

28. Palmieri, A.; Matthys, S.; Taerwe, L. Fire endurance and residual strength of insulated concrete beams strengthened with near-surface mounted reinforcement. J. Compos. Constr. 2013, 17 (4), 454-462.

29. Leone, M.; Matthys, S.; Aiello, M. A. Effect of elevated service temperature on bond between FRP EBR systems and concrete. Compos. Part B Eng. 2009, 40 (1), 85-93.

30. Firmo, J. P.; Correia, J. R.; Pitta, D.; Tiago, C.; Arruda, M. R. T. Experimental characterization of the bond between externally bonded reinforcement (EBR) CFRP strips and concrete at elevated temperatures. Cem. Concr. Compos. 2015, 60, 44-54.

31. Nigro, E.; Cefarelli, G.; Bilotta, A.; Manfredi, G.; Cosenza, E. Fire resistance of concrete slabs reinforced with FRP bars. Part I: Experimental investigations on the mechanical behavior. Compos. Part B Eng. 2011, $42(6), 1739-1750$.

32. Williams, B.; Bisby, L.; Kodur, V.; Green, M.; Chowdhury, E. Fire insulation schemes for FRP-strengthened concrete slabs. Compos. Part A : Appl. Sci. Manuf. 2006, 37 (8), 1151-1160.

33. Chowdhury, E. U.; Bisby, L. A.; Green, M. F.; Kodur, V. K. R. Investigation of insulated FRP-wrapped reinforced concrete columns in fire. Fire Saf. J. 2007, 42 (6-7), 452-460.

34. Qingfeng, W.; Wenfang, S. Kinetics study of thermal decomposition of epoxy resins containing flame retardant components. Polymer Degrad. Stab. 2006, 91 (8), 1747-1754.

35. Firmo, J. P.; Arruda, M. R. T.; Correia, J. R. Numerical simulation of the fire behaviour of thermally insulated reinforced concrete beams strengthened with EBR-CFRP strips. Compos. Struct. 2015, 126, 360370. 
36. Bai, Y.; Keller, T.; Correia, J. R.; Branco, F. A. ; Ferreira, J. G. Fire protection systems for building floors made of pultruded GFRP profiles part 2: modeling of thermomechanical responses. Compos. Part B Eng. 2010, $41(8), 630-636$.

37. López, C.; Firmo, J. P.; Correia, J. R.: Tiago, C. Fire protection systems for reinforced concrete slabs strengthened with CFRP laminates. Constr. Build. Mater. 2013, 47, 324-333.

38. Firmo, J. P.; Correia, J. R.; França, P.; Cabral-Fonseca, S. Fire protection systems for reinforced concrete beams strengthened with CFRP laminates. Lisbon Tech. Univ. Lisbon, 2010.

39. Palmieri, A.; Matthys, S.; Taerwe, L. Experimental investigation on fire endurance of insulated concrete beams strengthened with near surface mounted FRP bar reinforcement. Compos. Part B Eng., 2012, 43 (3) pp. 885-895.

40. Nigro, E.; Cefarelli, G.; Bilotta, A.; Manfredi, G.; Cosenza, E. Guidelines for flexural resistance of FRP reinforced concrete slabs and beams in fire. Compos. Part B Eng. 2014, 58, 103-112.

41. Nigro, E.; Cefarelli, G.; Bilotta, A.; Manfredi, G.; Cosenza, E. Fire resistance of concrete slabs reinforced with FRP bars part II: experimental results and numerical simulations on the thermal field. Compos. Part B Eng. 2011, 42 (6), 1751-1763.

42. Hawileh, R. A.; Naser, M.; Zaidan, W.; Rasheed, H. A. Modeling of insulated CFRP-strengthened reinforced concrete T-beam exposed to fire. Eng. Struct. 2009, 31 (12), 3072-3079.

43. Miano, V. U. Modelling composite fire behaviour using apparent thermal diffusivity. Ph.D. thesis dissertation for Newcastle University, England, 2011.

44. Dai J.-G., Gao W. Y., and Teng J. G., "Bond-Slip Model for FRP Laminates Externally Bonded to Concrete at Elevated Temperature,” J. Compos. Constr., vol. 17, no. 2, pp. 217-228, Apr. 2013.

45. Biscaia H. C., Chastre C., Viegas A., and Franco N., "Numerical modelling of the effects of elevated

46. Biscaia H. C., Chastre C., and Silva M. A. G., "Analytical model with uncoupled adhesion laws for the bond failure prediction of curved FRP-concrete joints subjected to temperature," Theor. Appl. Fract. Mech., vol. 89, pp. 63-78, Jun. 2017.

47. Gao W. Y., Teng J. G., and Dai J.-G., "Effect of temperature variation on the full-range behavior of FRP-to-concrete bonded joints,” J. Compos. Constr., vol. 16, no. 6, pp. 671-683, 2012. 
600 48. Gao W.-Y., Dai J.-G., and Teng J. G., “Analysis of Mode II debonding behavior of fiber-reinforced 601 polymer-to-substrate bonded joints subjected to combined thermal and mechanical loading," Eng. Fract. 602 Mech., vol. 136, pp. 241-264, Mar. 2015.

603 49. Nguyen, T. H.; Vu, X. H.; Si Larbi, A.; Ferrier, E. Experimental study of the effect of simultaneous 604 mechanical and high-temperature loadings on the behaviour of textile-reinforced concrete (TRC). Constr. 605 Build. Mater. 2016, 125, 253-270.

606 50. Feih S.; Mouritz, A. P. Tensile properties of carbon fibres and carbon fibre-polymer composites in fire. 607 Compos. Part A: Appl. Sci. Manuf. 2012, 43 (5), 765-772.

608 51. ANSYS. ANSYS Mechanical APDL Element Reference, Chapter 7: Element library, Release 15.0, $609 \quad$ November 2013.

610 52. ISO. ISO 834: Fire-Resistance Tests - Elements of Building Construction Part 1: General Requirements. 611 ISO/TC 92/SC 2, Sept. 1999. 